\title{
Jesuit Education in the Polish-Lithuanian Commonwealth (1565-1773)
}

\author{
Jakub Niedźwiedź \\ Jagiellonian University, Cracow \\ jakub.niedzwiedz@uj.edu.pl
}

\begin{abstract}
This article examines the impact of the Jesuit educational system on the culture of the multi-religious and multi-ethnic federation, through four problems. The first part of the paper presents the beginnings and development of the educational network and the Jesuit monopoly of education in the country. In the second part, it is shown how the Ratio studiorum was adapted to local conditions and how Latin culture was promoted in the Orthodox provinces of eastern Poland and Lithuania. One of the major consequences of these processes was the unification of a literary language and literature in Polish (Polish became the second language of Latinitas). The third part raises the question of the impact of rhetorical studies on political activity of the gentry, through the formation of the citizen-orator ideal. The development of literature, theatre, music, and the sciences forms the subject of the fourth part, which also lists the main achievements of Jesuit scholars and alumni. In conclusion, some observations are offered on the specific nature of Jesuit education in this part of Europe and its legacy after the dissolution of the Society of Jesus.
\end{abstract}

\section{Keywords}

Jesuits - Poland - Lithuania - early modern education - Polish-Lithuanian Commonwealth - Jesuit colleges - Polish literature 


\section{The Development of the Jesuit Scholar System}

In order to understand the specific position of Jesuit education in the PolishLithuanian Commonwealth, it is necessary to recall some facts about this country. From the sixteenth to the mid-eighteenth century, it was one of the largest states in Europe, its territory encompassing eight hundred thousand to one million square kilometers. It was a federation with two major members: the Polish Crown (contemporary Poland and Ukraine) and the Grand Duchy of Lithuania (contemporary Belorussia and Lithuania). ${ }^{1}$ It was established after several unions and treaties, the last of which was signed at Lublin in 1569 (the Union of Lublin). Despite the vast territory, the number of inhabitants was relatively low. ${ }^{2}$ The density of population was especially low in the eastern part of the Polish Crown. The Polish-Lithuanian Commonwealth was a multi-ethnic, multi-cultural, and multi-religious state. In the western part of Poland and Lithuania Roman Catholics held a dominant position but in the East the majority of inhabitants were Orthodox and Uniats. Throughout the entire country there were numerous settlements of Calvinists, Lutherans, Jews, and Muslims. The Jesuits had a difficult task when it came to dealing with such a complex religious situation. However, their educational system turned out to be their chief asset in the Commonwealth and shortly after establishing colleges in the country it brought them several successes.

In the mid-sixteenth century, there were no more than ten humanistic schools in Poland and Lithuania, and only one university (in Cracow). Many of the colleges were Protestant, especially in the Lutheran cities of Royal Prussia in north-western Poland. There were only two Catholic colleges and some parish schools in which elements of the humanistic curriculum were introduced. Most of these schools were located in the main Polish cities and in one or two cities in Lithuania. This situation reflected the situation of the Roman Catholicism in both countries immediately after the Council of Trent.

With the arrival of the Jesuits in Poland, the situation changed radically. Their first college was funded by Cardinal Stanisław Hozjusz in Braniewo

1 The territory of the Polish-Lithuanian Commonwealth covered also some areas of other contemporary states: Russia, Latvia, Estonia, Slovakia, and Moldova. Henryk Wisner, Rzeczpospolita Wazów. Czasy Zygmunta III i Wtadystawa IV (Warsaw: Neriton, Instytut Historii PAN, 2002), 14-34.

2 Witold Kula, Rozwój gospodarczy polski XVI-XVIII w. (Warsaw: Wydawnictwo PWN, 1993), 8o-84; Andrzej Wyczański, Polska w Europie XVI stulecia (Poznań: Wydawnictwo Poznańskie, 1999), 17-18; Cezary Kuklo, Demografia Rzeczypospolitej przedrozbiorowej (Warsaw: Instytut Historii PAN, 2009), 211-19. 
(Braunsberg) in $1565 .{ }^{3}$ Hozjusz was one of the key figures at the Council of Trent and understood the significance of education for Catholic Reform and Counter-Reformation very well. The choice of the place for this new college was not a coincidence. Braniewo was in Warmia, a Catholic region surrounded by Protestant Royal Prussia and Ducal Prussia, where several Lutheran humanistic schools flourished at the time. The college of Braniewo was supposed to end the supremacy of the Protestant schools in this region and give an opportunity for Catholic boys to study. This foundation determined the direction of the development of Jesuit educational network in this multi-religious country.

In the following decade, three more colleges were opened in Poland (Puttusk in 1566, Poznan in 1571, Jarosław in 1575) and one in Vilnius (Wilno), the capital of the Grand Duchy of Lithuania (1570). ${ }^{4}$ All of them followed the model of the school in Braniewo. The development of the Jesuit colleges was enforced by the establishment of two new provinces of the order: the Polish (1574) and the Lithuanian (1608). In 1756 and 1759, they were further divided into four provinces: the Lesser-Polish, Greater-Polish, Masovian, and Lithuanian. ${ }^{5}$

The Jesuit schools in the Polish and Lithuanian provinces constantly grew in number. In 1615, during the generalship of Claudio Aquaviva, they reached the number of twenty-two colleges. On the eve of the outbreak of the wars in the mid-seventeenth century, there were thirty-six schools in the two provinces. Most of them had a program of five classes, and in nine higher studies like philosophy and theology were also offered. By the end of the seventeenth century, there were forty-six colleges in Poland and Lithuania. ${ }^{6}$ In the year of the dissolution of the Society of Jesus the number reached its peak at sixty six. ${ }^{7}$

These statistics seem modest when compared to the number of schools in other European countries. For example, in France in 1616 there were as many as forty-six Jesuit schools, and by 1678 they reached the number of eighty three

3 Stanisław Załęski, S.J. Jezuici w Polsce, vol. 4, part 1: Kolegia i domy zatożone za królów Zygmunta Augusta i Stefana Batorego 1564-1588 (Cracow: Drukarnia W.L. Anczyca i Sp., 1905), 1-9.

4 Załęski, vol. 4, part 1: 38-44, 59-65, 109-116, Encyklopedia wiedzy o jezuitach na ziemiach Polski i Litwy, 1564-1995, ed. Ludwik Grzebień, S.J. (Cracow: Wydawnictwo WAM, 1996), 661.

5 Synopsis historiae Societatis Iesu, ed. Ludwig Schmitt (Ratisbonae: Typis Friderici Pustet, 1914), 586.

6 Stanisław Bednarski, S.J., Upadek i odrodzenie szkót jezuickich w Polsce: Studium z dziejów kultury i szkolnictwa polskiego (Cracow: Wydawnictwo Księży Jezuitów, 1933), 112.

7 Bednarski, Upadek, 112. 
colleges. ${ }^{8}$ In 1576 in Italy there were forty two colleges, by 1615 their number had almost doubled, up to seventy five. ${ }^{9}$

When it comes to the number of students, this was also lower than in the Italian or French colleges. Approximately 1300 boys studied in the biggest Polish college in Poznan in the $1620 .^{10}$ There were also around five schools in which the number of students exceeded seven-hundred, but in an average Polish or Lithuanian school there were no more than three- to four-hundred students. ${ }^{11}$ When we draw a comparison between the Polish-Lithuanian colleges and schools in other countries, there are distinct differences. French colleges were far bigger. In the 1620 s, almost two thousand students attended the college in Rouen, and there were other colleges of similar size elsewhere in France. ${ }^{12}$ An average French, Italian, or German college in the seventeenth century would have at least thirty percent more students than their PolishLithuanian counterparts. ${ }^{13}$

8 William V. Bangert, A History of the Society of Jesus, $2^{\text {nd }}$ ed. (St. Louis: Institute of Jesuit Sources, 1986), 214.

9 Bangert, History, 107.

10 Encyklopedia, 661.

11 Stanisław Załęski, S.J., Jezuici w Polsce, vol. 4, part 2: Kolegia i domy założone w pierwszej dobie rzadów Zygmunta III 1588-1608 (Cracow: Drukarnia W.L. Anczyca i Sp., 1905), 859; Kazimierz Puchowski, "Jezuickie kolegium i konwikt szlachecki w Kaliszu. Ze studiów nad edukacją w dawnej Rzeczypospolitej," in Jezuici w przedrozbiorowym Kaliszu: Materiatyz Sympozjum poświęconemu 4oo-leciu konsekracji kościota pw. św. św. Wojciecha i Stanistawa w Kaliszu, ed. Mariusz Bigiel (Kalisz: Edytor, 1996), 28.

12 François de Dainville, Léducation des Jésuites (XVIe-XVIIIe siècles), ed. Marie-Madeleine Compère (Paris: Éditions de Minuit, 1978), 122.

13 Claude Faure, Recherches sur l'histoire du collège de Vienne en Dauphiné (Paris: Editions Auguste Picard, 1933), 146; Gian Paolo Brizzi, La formazione della classe dirigente nel SeiSettecento. I seminaria nobilium nell'Italia centro-settentrionale (Bologna: Il Mulino, 1976); Gian Paolo Brizzi, "Le jésuites et l'école en Italie," in Les Jésuites à la Renaissance, système éducatif et production du savoir, ed. Luce Giard (Paris: Presses universitaires de France, 1995), 46; Istoria del Collegio di Mantova della Compagnia di Giesù, ed. Antonella Bilotto, Flavio Rurale (Mantua: Gianluigi Arcari, 1997), 21; Simona Negruzzo, "I collegi dei gesuiti in Alsazia: un assedio educativo," in Gesuiti e università in Europa (secoli XVI-XVIII): Atti del Convegno di studi (Parma, 13-15 dicembre 2001), ed. Gian Paolo Brizzi, Robert Greci (Bologna: Clueb, 2002), 120; Giancarlo Angelozzi, Alberto Preti, "Le scuole di via Castiglione: dal Gesuiti al Liceo statale," in Dal isola alla città: I gesuiti a Bologna, ed. Gian Paolo Brizzi and Anna Maria Mateucci (Bologna: Nuova Alfa, 1988), 136; Claudio Ferlan, Dentro e fuori le aule: La Compagnia di Gesù a Gorizia e nell'Austria interna (secoli 16.-17.) (Bologna: Il Mulino, 2012), 318-29; Emerich Coreth, Das Jesuitenkolleg Innsbruck. Grundzüge seiner Geschichte (Wien: Herder Verlag, 1991), 6; Carsten Rabe, Alma Mater Leopoldina. Kolleg und Universität der Jesuiten in Breslau 1638-1811 (Cologne: Böhlau, 1999), 23. 
However, these statistics tend to be deceitful. We have to bear in mind the considerably lower population density of the Polish-Lithuanian state, which resulted in the low density of the Jesuit school network, clearly visible on maps. ${ }^{14}$ In the eighteenth century, the distances between neighboring Jesuit schools were in some regions huge, up to one hundred and fifty kilometers. The provinces were extensive as well. In the Masovian province, the western colleges could be eight hundred kilometers away from the eastern ones. However, the network was more or less even. In practically every voivodship there was at least one school. As a result, even in the most remote regions of the vast country, young noblemen and burghers had a possibility to gain the knowledge and skills offered by a humanistic gymnasium.

This network dramatically changed the cultural landscape of the PolishLithuanian Commonwealth. In the first century after launching their first schools in Poland, the Jesuits practically gained a monopoly position in the field of high-school education in the country. It was only at the end of the seventeenth century that their dominance was broken by the Piarists, who established new schools with a more up-to-date program. Jesuit scholarship nevertheless had the greatest impact on the education of the elites of the Polish-Lithuanian Commonwealth.

\section{Education of the Citizens}

Although the objectives of Jesuit education were similar across the entire Roman Catholic world, ${ }^{15}$ they were accompanied by significant differences in its output. These differences can be observed even in relatively close countries, such as the Habsburg Empire and the Polish-Lithuanian Commonwealth. The organization of colleges in both monarchies shared many common features, but the application of the Ratio studiorum to the local conditions caused inevitable changes in the process of teaching and its results.

The objectives of Jesuit education were to form good Roman Catholics, citizens, and humanists. The means of achieving these goals was the liberal arts. The most important of these was the institutio oratoria-educational tools based on ancient, predominantly Roman, rhetoric. In the Polish-Lithuanian Commonwealth, this type of education was especially fruitful because of the state's political system. The king had relatively limited power and all important

\footnotetext{
14 Bednarski, Upadek (see a map added at the end of the book).

15 Ludwik Piechnik, S.J., Powstanie i rozwój jezuickiej Ratio studiorum (1548-1599) (Cracow: Wydawnictwo WAM, 2003).
} 
decisions had to be approved or taken by the Diet (Sejm). The members of the Diet were instructed by the voters who assembled at the regional diets in every voivodship before the parliamentary sessions. Every citizen, i.e. nobleman, had the right to express his political opinions and to try to convince other citizens of them. There was a place for public debate. Thus, political rhetoric (the genus deliberativum) was especially cultivated in the Polish-Lithuanian state. The Jesuit educational system played crucial role in preparing young generations for their future political positions.

We do not know much about the students of the Jesuit colleges in Poland and Lithuania. In every school registers of students were maintained in which the teachers noted the personal data, personality traits, and progress of their pupils. To some extent, these registers followed the pattern of the annual catalogues in which members of the Society were characterized. Unfortunately, scarcely any of these student registers have survived. We can widen our knowledge about the students using other sources, such as the catalogues of the Sodalities of Our Lady. There are also several printed and manuscript poetic anthologies composed in the colleges, containing some names of authors.

It is highly probable that the Jesuit schools were attended mostly by the sons of the gentry. In the first half of the seventeenth century, in the college of Ostroh (Ostróg) a good half of the students were noblemen. ${ }^{16} \mathrm{~A}$ similar situation can be observed at the Jesuit university in Vilnius. A surviving register of the members of the Sodality of Our Lady of the Vilnius Academy includes mainly young noblemen. ${ }^{17}$ In Masovia, where the percentage of the impoverished gentry was the highest in the entire Polish-Lithuanian state, the colleges of Pułtusk, Płock, and Rawa were overcrowded with the sons of the gentry. It can be supposed that free studies in a Jesuit college could give a young nobleman a chance for some sort of career.

In the eighteenth century, studies at Jesuit or Piarist colleges became a standard path of education for young Polish or Lithuanian noblemen. Some new special colleges, the collegia nobilium, were established for the wealthy members of gentry and magnates. ${ }^{18}$ These schools imitated similar institutions widespread abroad. They had a new curriculum, no longer based on the Ratio

16 Тетяна Шевченко, Єзуїтське шкільниитво на украӥнських землях останньої чверті XVI-cередини XVII cm. (Lviv: Свічадо - Товариство Iсуса, 2005), $15^{2}$.

17 Catalogus sodalium, cui ab anno Domini 1667 Sodalitati Immaculatae Conceptionis B.V.Mariae in Academia Vilnensi Societatis Iesu adscritpi sunt reformatus anno Domini 1683, Biblioteka Uniwersytetu Jagiellońskiego, Cracow, Ms BJ 4557.

18 Kazimierz Puchowski, Jezuickie kolegia szlacheckie Rzeczypospolitej Obojga Narodów. Studium z dziejów edukacji elit (Gdańsk: Wydawnictwo Uniwersytetu Gdańskiego, 2007). 
studiorum, and were both exclusive and expensive. The "normal" colleges were still available free of charge, but the process of their modernization was slower.

Even in these traditional colleges, noblemen formed the largest percentage of the student body. We can thus assume that an average college was a school for the gentry. The cross-section of the social background of the students in Polish and Lithuanian colleges differed from those of colleges in other European countries. The percentage of young French noblemen in the colleges in western France in the seventeenth century did not exceed ten percent. The vast majority of the pupils were the sons of burghers and artisans. ${ }^{19} \mathrm{~A}$ similar situation obtained in the states of northern Italy. However, it is worth noting that the different political contexts of these countries. A nobleman studying in Mantua, Toulouse, or Sandomierz gained similar rhetorical competences, but had completely different possibilities when it came to the use of their skills outside the college.

What kind of career did an education from such a college offer in the PolishLithuanian Commonwealth? It is not easy to answer this question, since we have few records of the alumni. Among them there are more or less famous poets, including Samuel Twardowski, Kasper Twardowski, Hieronim Morsztyn, Jan Chryzostom Pasek, Stanisław Samuel Szmiot, Maciej Kazimierz Sarbiewski, Albert Ines, or Józef Baka. What did the alumni do? Most were landowners, some also had military or court careers. Sarbiewski, Ines, and Baka became Jesuits themselves. These examples may not be absolutely representative, but quite probably they reflect the general tendency. Jesuit education granted young noblemen access to some kind of public career: they could work as lawyers, officials, or priests. But first of all it gave them the rhetorical tools necessary for the homines rhetorici-active participants of political and social life. A side effect of instructing future politicians and officials in rhetoric was a dramatic development in literature and other arts.

\section{Languages, Literature, and New Readership}

Before the Jesuits came to the Polish-Lithuanian state, a relatively limited group of well-educated humanists had lived there. Most of them studied at the universities in Cracow and abroad, mainly in Italy and Germany. This highly qualified personnel was absorbed by the main state and church offices and

19 Dainville, L'éducation, 122; Claude Faure, Recherches sur l'histoire du collège de Vienne en Dauphiné (Paris: Editions Auguste Picard, 1933), 146. 
courts. ${ }^{20}$ Humanistic literature in Latin and Polish, though flourishing, was known only in the cities and in the royal and aristocratic courts and chanceries.

This situation changed during the last decades of the sixteenth century, when a new group of readers and writers appeared. One of the main factors in these changes was the establishment of the Jesuit educational network. Every year thousands of boys had to study Latin grammar and rhetoric, read and learn by heart Latin classics, and compose their own poems and speeches. They could act on stage in the school theatre and compete in literature with their peers in class. It resulted in the formation of a numerous non-elite humanistic audience.

They were able to express their new cultural needs and expectations. First of all, the quantity of literary production grew. ${ }^{21}$ This was reflected in the establishment of printing houses and the growth of the market for books, but also in a huge number of commonplace books written in the seventeenth and eighteenth century. Manuscript copies of political poems circulated throughout the entire country. During the Zebrzydowski Rebellion in 1606-7, both sides of the conflict widely used humanistic propaganda texts. ${ }^{22}$ It can be supposed that Jesuit schools accelerated the spread of literary culture.

The Jesuits set high standards of literary education. First of all, students had to possess a thorough knowledge of humanist Latin. Consequently, a vast part of male society gained a common, standardized language of written communication. But there is yet another aspect of this process of the unification of the language: in the Jesuit colleges, Polish, used as an auxiliary language of instruction, was standardized as well. At the beginning of the seventeenth century, inspectors from Rome, visiting schools in the province of Poland, noticed that not all the students spoke and wrote Polish correctly. Thus, the teachers were obliged to correct not only Latin but also the Polish texts written by the young boys of the grammar classes. ${ }^{23}$

According to the Ratio studiorum, Polish and Lithuanian Jesuits cultivated a specific form of reading and writing in their colleges. The readings were limited mainly to the Roman authors (Cicero, Horace, Ovid, Virgil, Seneca, Martial,

20 Mirosław Korolko, Seminarium Rzeczypospolitej Królestwa Polskiego. Humaniści w kancelarii królewskiej Zygmunta Augusta (Warsaw: Wiedza Powszechna, 1991).

21 Daiva Narbutienė, Lietuvos Didžiosios Kunigaikštijos lotyniškoji knyga XV-XVII a., (Vilnius: Lietuvių literatūros ir tautosakos institūtas, 2004), 106-9.

22 Juliusz Nowak-Dłużewski, Okolicznościowa poezja polityczna w Polsce. Zygmunt III (Warsaw: Instytut Wydawniczy PAX, 1971), 117.

23 "Proposita provinciae Lithuaniae de studiis humanioribus promovendos anno 1609," in Monumenta Paedagogica Societatis Iesu. Nova editio penitus retractata, vol. 7, ed. Ladislaus Lucács, S.J., (Rome: Institutum Historicum Societatis Iesu, 1992), 414. 
etc.). Young readers were to find moral virtues in the selected texts, widen their classical erudition, polish their Latin, and exercise their memory. They were inculcated with the humanist method of reading with a pen in hand. ${ }^{24}$ This was interactive reading and often meant copying or commenting upon the material they read. In short: reading was tightly tied to recording a text and to its transformation, either in one's memory or in one's commonplace book. Consequently, many of the young noblemen who graduated from Jesuit schools had a habit of writing constantly.

In the Jesuit schools, students were supposed to compose their own original texts, both in prose and in verse. They started their literary education in the grammar classes, with short rhetorical exercises, the Praeexercitamina, such as fables, sentences, descriptions, narrations, and chria. ${ }^{25}$ The next step wereletters and simple Latin verses: epigrams and epitaphs. In the class of the Humaniora they composed more sophisticated texts: odes, elegies, elogia, bucolics, panegyrics, heraldic poems (stemmata), emblems, and hieroglyphics. ${ }^{26}$ In the final class of rhetoric they wrote speeches. All these texts were presented publicly in front of the class, the entire college, or external audiences during open days.

Composing texts required of the students a basic knowledge of literary criticism. They obtained it especially in the two upper classes (Poetica and Rhetorica). This knowledge was adjusted to the age and needs of the pupils. These adaptations can be traced through many surviving textbooks. ${ }^{27}$ All of

24 Antony Grafton, "The Humanist as Reader," in A History of Reading in the West, ed. Guglielmo Cavallo and Roger Chartier, transl. Lydia G. Cochrane (Amherst: University of Massachusetts Press, 1999), 179-212.

25 Bartosz B. Awianowicz, Progymnasmata w teorii i praktyce szkoty humanistycznej od końca $X V$ do potowy XVIII wieku. Dzieje nowożytnej recepcji Aftoniosa od Rudolfa Agricoli do Johanna Christopha Gottscheda (Toruń: Wydawnictwo Uniwersytetu Mikołaja Kopernika, 2008).

26 The teachers themselves wrote poetry and prose in the same genres. Janusz S. Gruchała, "Latin Poetry Written by Polish Jesuits in the Seventeenth Century: From Horatian Parody to Elogium," in Motiejus Kazimieras Sarbievijus lietuvos, lenkijos, europos kultūroje. Tarptautines mokslines konferencijos, skirtos poeto 40o-uju gimimo metiniu jubiliejui, medžiaga. Vilnius, 1995, spalio 19-21, ed. Eugenija Ulčinaitè (Vilnius: Lietuvių literatūros ir tautosakos institutas, 1996), 175-91.

27 Teresa Michałowska, Staropolska teoria genologiczna (Wrocław: Ossolineum, 1974); Eugenija Ulčinaitè, Teoria retoryczna w Polsce i na Litwie w XVII wieku. Próba rekonstrukcji schematu retorycznego (Wrocław: Ossolineum, 1984); Ann Moss, Printed CommonplaceBooks and the Structuring of Renaissance Thought (Oxford: Oxford University Press, 1996), 134-85; Jakub Niedźwiedź, Nieśmiertelne teatra stawy. Teoria i praktyka twórczości panegirycznej na Litwie w XVII-XVIII w. (Cracow: Księgarnia Akademicka, 2003). 
them are in manuscript - in Polish and Lithuanian colleges the use of printed manuals was rare. A normal practice was to dictate the rules to the students, who wrote them down in their personal notebooks. The vast majority of these manuscripts was written in the second half of the seventeenth and the first half of the eighteenth century. Sometimes these books have an elaborate literary form, but the content is not very complex. The rules are succinct and followed by many examples from ancient or contemporary texts, with some exceptions.

In the 168os, in Vilnius and in the other Lithuanian colleges, lectures on Polish poetry were introduced. Verses and speeches in Polish had been previously composed in the schools of both provinces, and we find many Polish-language excerpts in school commonplace books. However, it was the first time that Polish versification was systematized and codified. The Polish versification system was a section of a lecture about Latin meters. The Latin part was exemplified mainly with fragments of Horace's odes. ${ }^{28}$ In the Polish part the vast majority of the examples was taken from the works of Jan Kochanowski (1530-84). He was the most distinguished Polish Renaissance poet and his influence on Polish literature cannot be overestimated. In Jesuit schools in the seventeenth century he played as important a role as Horace or Virgil.

Introducing Polish poetics was quite an important modification of these parts of Ratio studiorum, which provided for literary and rhetorical education based mainly on classical literature. ${ }^{29}$ This change must have been accepted by the authorities of the province, but a formal approval has not yet been found in the Jesuit archives. This move by the professors in Vilnius is a clear sign of the gradual replacing of the classical literary tradition by a Polish one. The first step in this process was establishing a new national canon of texts and authors. Kochanowski became its brightest star, but there were also other authors to be imitated: the successful epic poet Samuel Twardowski (1595-1661) and Maciej Kazimierz Sarbiewski. In the mid-eighteenth century, Polish literature became one of the main subjects in the reformed Piarist and Jesuit schools.

28 Jakub Niedźwiedź, "Sylabotonizm Jana Kochanowskiego i teoria wersyfikacji polskiej w XVII w., Terminus 14 (2006): 179-87.

29 It is worth to mention that Ratio studiorum provided contact not only with Classical literature but with other texts as well. Among them there were: catechism study, listening to sermons, examining Greek Fathers (e.g. John Chrysostom). The main purpose of these literary studies was to prepare a student to the studia superiora-philosophy and theology. 
Another example of this complex approach to literary criticism are the lectures on poetics recorded in 1626 and 1627 by the students of the college at Połock. They were delivered by the aforementioned Professor Maciej Kazimierz Sarbiewski (1595-1640), one of the most famous European poets of the seventeenth century. ${ }^{30} \mathrm{He}$ put forward a new theory of conceptual poetry and coined a definition of conceit (concordia discors or discordia concors). ${ }^{31}$ Sarbiewski's educational talents were also employed at the Vilnius Academy where he worked as a professor of philosophy and theology.

The Vilnius Academy (Academia Vilnensis) in the capital of Lithuania was the only Jesuit university in the Polish-Lithuanian Commonwealth. ${ }^{32}$ The Society made efforts to open two more universities in Lviv (Lwów) and Poznań, but their projects were initially scuttled by the professors of the royal University of Cracow, who wished to protect their monopoly on university education in the Polish Crown. ${ }^{33}$ The Lviv Academy was ultimately opened only in 1661 . Nevertheless, some large colleges in Poland, together with the Vilnius Academy, provided good opportunities for those interested in higher studies. The most distinguished disciplines taught were mathematics, logics, astronomy, theology, and (in Vilnius) law.

However, philosophy and theology were not very popular in the Jesuit colleges in the Polish-Lithuanian Commonwealth. The future religious and priests chose them, but an average student finished his education at the earlier stages. This humanistic, literary-based education seemed to suffice for most young noblemen and burghers.

$30 \quad$ Jozef Ijsewijn, "Mathias Casimirus Sarbievius, Ad amicos Belgas," in Motiejus Kazimieras Sarbievijus, 25-28; Dirk Sacré, "Etiamsi in tual laudes totum conspiret Belgium. Aspects of Sarbievius's Nachleben," in Motiejus Kazimieras Sarbievijus, 109-32; Krzysztof Fordoński, "Maciej Kazimierz Sarbiewski and English Dissenting Poets of the Early $18^{\text {th }}$ Century: A Study in Reception of Neo-Latin Poetry in Great Britain," Terminus 13 (2011): 71-85.

31 Some of the treatises by Sarbiewski have since been published: Maciej Kazimierz Sarbiewski, O poezji doskonatej, czyli Wergiliusz i Homer. De perfecta poesi, sive Vergilius et Homerus, transl. Marian Plezia, ed. Stanisław Skimina (Wrocław: Ossolineum, 1954); Wyktady poetyki. Praecepta poetica, transl. and ed. Stanisław Skimina (Wrocław: Ossolineum, 1958); Dii gentium. Bogowie pogan, ed. and transl. Krystyna Stawecka (Wrocław: Ossolineum, 1972).

32 Ludwik Piechnik, S.J., Początki Akademii Wileńskiej 1570-1599 (Rome: Institutum Historicum Societatis Iesu, 1984); Ludwik Piechnik, Rozkwit Akademii Wileńskiej w latach 160o-1655 (Rome: Institutum Historicum Societatis Iesu, 1983); Ludwik Piechnik, Próby odnowienia Akademii Wileńskiej po klęskach Potopu i okres kryzysu 1655-1730 (Rome: Institutum Historicum Societatis Iesu, 1987).

Załęski, Jezuici, vol. 4, part 2, 617-18. 


\section{The Transfer of Educational Technologies and the Discourse of Domination}

Even though the Jesuits were not the first to introduce a humanistic curriculum in high schools in Poland and Lithuania, their project became the most successful and influential. First of all, they provided students with highly qualified teachers and a coherent and effective program of studies. Secondly, their wide network enabled young boys to gain humanistic education even in the most distant provinces of the country. Thirdly, the Jesuits offered their education for free. And finally, they allowed non-Catholics to study at their colleges. These four advantages of Jesuit schools offered a real challenge to the Protestants and the Orthodox.

The situation in Vilnius serves as a good example of this situation. In the 1560 s, there was quite a good Calvinist college in the city. ${ }^{34}$ When the Jesuits established their own school in 1570, the troubles for the Calvinists began. In order to successfully compete with the Catholics they had to maintain high standards of teaching. It was not easy because the Jesuits could afford the best professors. Meanwhile the Calvinists suffered from a permanent lack of good teaching staff. As a result, Calvinist parents often sent their sons to the Jesuit colleges and no amount of prohibitions by the Calvinist authorities worked to deter them. ${ }^{35}$

Another problem were the persistent attacks against the Calvinist church and school in Vilnius. Jesuit students often participated in these riots. ${ }^{36}$ Eventually, in the first half of the seventeenth century, the Calvinists had to reduce their school to the elementary level and set up new colleges in the distant towns of Slutsk (Słuck) and Kèdainiai (Kiejdany), where there were no Jesuit schools. Nevertheless, the Protestants still had to watch the Jesuit methods and to some extent use them in their own schools.

The Jesuit colleges also stimulated the Orthodox. The latter understood that without high schools with the new type of humanistic curriculum, they were going to lose their battle against the Catholics and Protestants. In the 1580 , the first Orthodox brotherhood schools were established in Vilnius and Lviv, and

34 Ingè Lukšaitè, Reformacija Lietuvos Didžiojoje Kunigaikštystèje ir Mažojoje Lietuvoje XVI a. trečias dešimtmetis-XVII a. pirmas dešimtmetis (Vilnius: Baltos Lankos, 1999), 468-69.

35 Akta synodów prowincjonalnych Jednoty Litewskiej 1621-1637, ed. Marzena Liedke and Piotr Guzowski (Warsaw: Semper, 2011), 36.

36 Bogumił Zwolski, "Zburzenie zboru ewangelicko-reformowanego w Wilnie w 1682 r.," Ateneum wileńskie 12 (1937): 482-514. 
then in some other towns of contemporary Belorussia, Poland, and Ukraine. ${ }^{37}$ The Orthodox brotherhood schools imitated the program of the Jesuit colleges. The most important was the Mohyla College founded in Kyiv (Kijów) in 1632. ${ }^{38}$

In the first half of the seventeenth century, the Jesuit model of education became a standard, even in non-Catholic schools, throughout the entire Polish-Lithuanian Commonwealth. ${ }^{39}$ Most of these schools had five classes, a program built around Latin, rhetoric, Classical literature, basic theology, and theatre. As a result, the male élite, regardless of confession, had a similar educational background. This helped in building social communication and a basis for early modern Polish and Lithuanian national identities. Jesuit education also included the humanistic idea of personal independence, subsuming a long tradition of classical, medieval, and renaissance philosophy and literature. These ideas had an immense influence on Polish-Lithuanian republican ideology in the seventeenth and eighteenth centuries. They also maintained among the gentry a sense of personal and political freedom, considered to be essential of the political system of the Commonwealth.

On the other hand, the élite was dominated by a single cultural option. In the state, where the Roman Catholic option prevailed in the second half of the seventeenth century and where Protestants and Orthodox were prosecuted, the choice of the Jesuit-Catholic model was a form of political and cultural mimicry. This process was complex, long-term, and caused by many factors, but it is worth bearing in mind that the Jesuit colleges contributed to the fact that the vast majority of the middle class of gentry and burghers in the

37 Juliusz Bardach, "Bractwa cerkiewne na ziemiach ruskich Rzeczypospolitej w XVI i XVII wieku," Kwartalnik Historyczny 74, no. 1 (1967): 77-82; Antoni Mironowicz, "Szkolnictwo prawosławne w Rzeczypospolitej," in Szkolnictwo prawosławne w Rzeczypospolitej, ed. Antoni Mironowicz, Urszula Pawluczuk, and Piotr Chomik (Białystok: Zakład Historii Kultur Pogranicza Instytutu Socjologii Uniwersytetu w Białymstoku, 2002), 18-39.

38 Aleksander Jabłonowski, Akademia Kijowsko-Mohilańska. Zarys historyczny na tle rozwoju ogólnego cywilizacyi zachodniej na Rusi (Cracow: Drukarnia A.L. Anczyca i Sp., 1899-1900), 97-102; Ryszard Łużny, Pisarze kręgu Akademii Kijowsko-Mohylańskiej a literatura polska. Z dziejów związków kulturalnych polsko-wschodniostowiańskich w XVII-XVIII w. (Cracow: Państwowe Wydawnictwo Naukowe, 1966); Rostisław Radyszewśkyj, Polskojęzyczna poezja Ukraińska od końca XVI do początku XVIII wieku, cz. 1: Monografia (Cracow: Ossolineum, 1996), 88 and 144 .

39 The Jesuit model of education was applied also in the colleges of the Unites, opened since the end of the seventeenth century. The exceptions were some Protestant schools: the Lutheran gymnasia in Gdańsk, Elbląg, and Toruń, the Academy of Raków, held by the Polish Brethern and the college of the Czech Brethren in Leszno, founded by Jan Ámos Komenský (Comenius) in 1626. 
multi-religious and multi-cultural country became Roman Catholics in the eighteenth century.

\section{Conclusion}

The Jesuit educational system in the Polish-Lithuanian Commonwealth played an important role in many areas of the region's cultural, political, and social life. The main objective of Jesuit education was to form new generations of well-educated Roman Catholics. By this means the Jesuits enforced Catholicism in the country and contributed to the diminishing of the role of the Reformed and the Orthodox churches.

They promoted humanitas christiana, based on Classical literature and rhetoric. The ideological core of this literature was Stoic philosophy and the Roman civil ethos, with such moral and political categories as Stoic virtue (virtus), the priority of rationality over emotions, patriotism (amor patriae), a sense of common weal, republicanism, and so on. It was not a mass education, but nevertheless it strongly influenced a major part of the political élite. The Jesuits supplied these men with a coherent language and terms to develop the state and the national discourse of the time.

In the first decades of their activity in the commonwealth, the Jesuits' educational program quickly widened the group of reasonably well educated men. The level of advanced literacy increased. This in turn influenced the development of literary activity and new readership, and shaped the literary tastes of the middle class as well. As a result, Polish literature flourished in the seventeenth century.

There were also some disadvantages. The Jesuit educational system in Poland and Lithuania was not flexible enough. It was largely impervious to new ideas, and gradually became a bastion of stiffly conservative forms of thought. In the first decades of the eighteenth century, its educational goals were similar to those of a hundred years earlier. Thus, the Jesuit schools were not able to face the challenges of the modern world.

It was only in the 1750 s that reforms were introduced. These were inspired by the modern curricula of the Piarists, who were the Jesuits' main competitors in the field of higher education. The reformed schools offered a modern division of subjects in the educational process. Geography, mathematics, history, Polish literature, and modern languages were all taught. ${ }^{40}$

40 Bednarski, Upadek, 234-374. 
Jesuit schools played an important role in the Polonization of the élite. In the vast multi-cultural and multi-lingual state, Polish became the standard and principal language of written and oral communication. It became also the language of high culture. The descendants of Ruthenian (Ukrainian and Belorussian), Lithuanian, Livonian, and Prussian gentry gradually gained Polish national identity. This was a complex process and the Jesuit schools were not the only factor contributing to these changes. However, the Jesuits promoted two standard languages and literatures: Latin and Polish. Two hundred years of their activity in all parts of the Polish-Lithuanian Commonwealth must have had a strong influence on the shape of literary communication among the élite.

In 1773, the Society of Jesus was suppressed in the Polish-Lithuanian Commonwealth. However, this did not mean that their educational network was annihilated and their schools abandoned. On the contrary, all of these institutions were taken over by the state and reorganized. Parliament set up the first ministry of education in Europe: the Commission of National Education (Komisja Edukacji Narodowej). Modern programs and textbooks were prepared and Latin was replaced by Polish as the main language of instruction, but most of the teachers in this new system were ex-Jesuits.

Most of these reformed schools survived the partitions of the PolishLithuanian Commonwealth in the second half of the eighteenth century. They were transformed by the occupiers but they carried on the traditions of Jesuit education without any major breaks. Among them are high schools in Kalisz, Przemyśl, Pułtusk, and Sandomierz in Poland that continue in operation to this day 